\title{
Review of Greenhouse Gas Emissions from Rewetted Agricultural Soils
}

\author{
Andrea Bianchi ${ }^{1} \cdot$ Tuula Larmola $^{1} \cdot$ Hanna Kekkonen ${ }^{1} \cdot$ Sanna Saarnio $^{1} \cdot$ Kristiina Lång $^{1}$ (i)
}

Received: 8 April 2021 / Accepted: 12 October 2021 / Published online: 6 November 2021

(C) The Author(s) 2021

\begin{abstract}
Climate policies encourage the search for greenhouse gas (GHG) mitigation options in all economic sectors and peatland rewetting is one of the most efficient mitigation measures in agriculture and land use. The benefits shown in the national GHG inventories, however, depend not only on the actual mitigation actions on the ground but also how well the effects can be reported. Currently there are no specific emission factors for reporting GHG emissions from rewetted agricultural soils as the current emission factors are aggregated for several pre-rewetting land use types. Also, rewetting can aim at either restoration or different forms of paludiculture which may differ in their GHG profile and thus demand disaggregated emission factors. We compiled the current knowledge on GHG emissions on sites where rewetting has occurred on former agricultural peatland in temperate or boreal climate zones. The recent data suggest that on average the current emission factors for rewetting nutrient-rich sites published by the Intergovernmental Panel for Climate Change (IPCC) provide a good estimate for reporting emissions from rewetting in the temperate zone. However, the total GHG balances differed widely in restoration, Sphagnum farming and production of emergent plants in paludiculture and it is evident that disaggregated emission factors will be needed to improve the accuracy of reporting the effects of mitigation measures in the GHG inventories.
\end{abstract}

Keywords Peatland $\cdot$ Climate $\cdot$ GHG $\cdot$ Rewetting $\cdot$ Paludiculture $\cdot$ Emission factor

\section{Introduction}

Although peat soils cover only $3-4 \%$ of the global surface area they hold at least $30 \%$ of the global soil organic carbon, about 450-700 Gt (Xu et al. 2018; IPCC 2019). Peat accumulates because the low level of oxygen in watersaturated soils reduces aerobic degradation activity, slowing down the decomposition rate of litter and so the carbon dioxide $\left(\mathrm{CO}_{2}\right)$ release (Yu 2012). Conversely, anaerobic bacteria and archaea can carry on the decomposition of organic matter in the absence of oxygen, resulting in methane $\left(\mathrm{CH}_{4}\right)$ emissions (Saarnio et al. 2009; Couwenberg and Fritz 2012). Generally, the release of carbon in the form of $\mathrm{CH}_{4}$ is offset by the net $\mathrm{CO}_{2}$ uptake (Hemes et al. $2018)$ and nitrous oxide $\left(\mathrm{N}_{2} \mathrm{O}\right)$ emissions are negligible in undrained peat soils (Regina et al. 1996). Although a natural site can release $\mathrm{C}$ during drought (Saarnio et al. 2007), on average the gross primary production (carbon

Kristiina Lång

kristiina.lang@luke.fi

1 Natural Resources Institute Finland (Luke),

Latokartanonkaari 9, FI-00790 Helsinki, Finland uptake) is higher than the ecosystem respiration (carbon release), resulting in a net build-up of a peat layer (IPCC 2006; Joosten et al. 2016).

Despite their importance as long term carbon stocks and their high ecological value, peat soils are deeply threatened by human activities which may have a significant long-term impact on their carbon balance and their provisioning of ecosystem services (Chimner et al. 2017). Agriculture, forestry, land-use intensification, peat extraction and infrastructure development are the main drivers of peatland drainage (Tanneberger et al. 2020). Such human intervention turns peat soils from sinks to sources of carbon. The drainage process lowers ground water level and lets oxygen into the peat, thereby enhancing its aerobic decomposition which results in high $\mathrm{CO}_{2}$ emissions (Joosten et al. 2016). While $\mathrm{CH}_{4}$ fluxes from drained peat soils are very low or negligible, $\mathrm{N}_{2} \mathrm{O}$ emissions can be significant, especially in nitrogen-rich sites (Leppelt et al. 2014). Thus, agricultural peatlands are usually a strong source of GHGs (Leifeld and Menichetti 2018). It has been estimated that at least $12 \%$ of natural peatlands has been drained globally, leading to their progressive degradation (Joosten 2016). Drained peatlands contribute up to $5 \%$ of 
global GHG emissions with an estimated net flux of 0.9-3 Gt $\mathrm{CO}_{2}$ year $^{-1}$ (Joosten 2016; IPCC 2019).

In order to reduce the GHG emissions from drained peatlands and to re-establish their role as carbon sinks and their capacity to provide essential ecosystem services, the necessity to restore their hydrological and ecological conditions is increasingly recognised (Leifeld and Menichetti 2018; Tanneberger et al. 2021). The concept of restoration denotes all the practices required to assist the recovery of a specific ecosystem after its degradation, damage or destruction (SER 2004). In the case of drained peatlands, it comprises raising the water table and enabling the recovery of ecosystem services. The more disturbed the ecosystem is the more difficult is the full restoration of ecosystem functions, and for agriculturally used lands it may be impossible (Joosten 2016).

Rewetting limits peat mineralization which leads to reduced $\mathrm{CO}_{2}$ emissions (Strack and Zuback 2013) and negligible $\mathrm{N}_{2} \mathrm{O}$ emissions due to lower availability of mineral nitrogen in saturated conditions (Schrier-Uijl et al. 2014). The reactivation of anaerobic respiration, on the other hand, increases the release of $\mathrm{CH}_{4}$ (Joosten et al. 2016; Jensen et al. 2017). A large number of studies have demonstrated the effectiveness of rewetting in restoring the carbon sink capacity of peat soils similar to natural undrained peatlands (Schrier-Uijl et al. 2014; Renou-Wilson et al. 2016; Nugent et al. 2018; D'Acunha et al. 2019). In other cases, rewetting has not been able to re-establish the carbon sink function (at least in a short-term period) but still highly reduce the emissions compared to drained sites (Strack and Zuback 2013; Renou-Wilson et al. 2016; Wilson et al. 2016a).

This decade was nominated the Decade on Ecosystem Restoration by the United Nations (UN 2019). If this together with different climate and biodiversity targets boosts rewetting it is essential to have reliable estimates of the climate change mitigation potential following rewetting. At country level, accurate data on the emissions and removals of these practices are needed for national GHG inventories. Within the United Nations Framework Convention on Climate Change (UNFCCC), the signatory countries belonging to Annex I, have to report their annual GHG inventory for the different economic and land-use sectors. The UNFCCC protocols require that the Parties use the 2006 IPCC Guidelines for National Greenhouse Gas Inventories, which provide internationally recognised methodologies to estimate GHG budgets at country levels. Volume 4 of the 2006 IPCC Guidelines comprises procedures and equations needed to prepare annual inventories for agriculture and land use and, more specifically, chapter 7 refers to managed wetlands (IPCC 2006). However, the latter did not include methodologies specific to rewetting of peatlands. In 2014, the IPCC published the Wetlands Supplement to the 2006 Guidelines in order to provide a broader coverage on wetlands and updated methodologies in the light of new available scientific information, including data and procedures for rewetted organic soils (IPCC 2014; Chapter 3). The most straightforward and widely used Tier 1 methodology implies that the national area of rewetted soils is multiplied by a coefficient defining the emissions or removals of $\mathrm{CO}_{2}$ and $\mathrm{CH}_{4}$ per hectare in a year, i.e. the emission factor (EF), disaggregated by climate zone and nutrient status. Within the Tier 1 approach, $\mathrm{N}_{2} \mathrm{O}$ emissions from rewetted soils are considered negligible and are not accounted for. The IPCC EFs for rewetted organic soils are derived from an extensive literature review with data from both undrained and rewetted sites (Wilson et al. 2016b).

EFs for boreal and temperate zones in the IPCC Wetlands Supplement include data from papers published up to the year 2011 and 2013, respectively. Since then, new studies on rewetting have been published, and more data on GHG fluxes from rewetted agricultural peat soils are now available. The peat degradation and nutrient status are generally higher in the agricultural sites than in the less intensively managed peatlands and it is still unknown how well the existing aggregated emission factors are suited for reporting the GHG emissions from rewetted agricultural sites. For this reason, we conducted a literature review to summarize the more recent information on GHG emissions and removals associated with rewetting agricultural sites in temperate and boreal regions. The aims of this study were 1) to estimate whether there are sufficient data available for emission factors for rewetting of agricultural soils and 2) how much the different rewetting types of agricultural soils differ with respect to their GHG emissions.

\section{Materials and Methods}

Field studies on sites where former agricultural land (cropland or grassland) had been rewetted and the annual average water table depth was equal or shallower than $0.25 \mathrm{~m}$ were included in this analysis. Also naturally wet meadows with an agricultural background were included. We made one exception to the criteria on former land use: the Sphagnum site reported in (Beyer and Hoeper 2015) which was a former peat mining area was included as removal of the agriculturally affected topsoil is a common practice in Sphagnum farming and thus the former land use has less impact on the results of rewetting. Only peer-reviewed papers reporting annual flux estimates were chosen. We report average annual values for $\mathrm{CO}_{2}, \mathrm{CH}_{4}$ and $\mathrm{N}_{2} \mathrm{O}$ fluxes per hectare and year for three categories: restoration to natural conditions, paludiculture with Sphagnum farming and paludiculture of emergent biomass crops as well as all of these combined. Carbon in harvest was included in the estimate of annual $\mathrm{CO}_{2}$ balance in the estimates for emergent plants if harvesting was done. 
Global warming potentials 27.2 and 273 were used for $\mathrm{CH}_{4}$ and $\mathrm{N}_{2} \mathrm{O}$, respectively, to convert the results to $\mathrm{CO}_{2}$ equivalents (Canadell et al. 2021). Methane emissions from ditches or $\mathrm{CO}_{2}$ emissions from dissolved carbon were left out from this comparison as measurement results were rarely available. We did not attempt to disaggregate the results by climate zone as according to the climatic zone classification of FAO (2001) used by the IPCC, only the study of Wang et al. (2018) originates from the boreal climatic region. All the other references were from temperate regions.

Differences between the annual GHG rates of the management types were tested using the generalized linear model analysis method of SAS EG software (version 7.1). The values for annual fluxes were log-transformed to normalise their distribution.

\section{Results and Discussion}

Restoring highly degraded agricultural sites to conditions corresponding to natural peatlands is challenging but our data compilation showed that fairly favourable GHG balances can still be expected. In general, restored sites likely turn into sinks of $\mathrm{CO}_{2}$ while emissions of $\mathrm{CH}_{4}$ and $\mathrm{N}_{2} \mathrm{O}$ are high enough to make these sites small net sources of GHGs (Table 1). The measured emission rates are similar to the IPCC emission factors for rewetting nutrient-rich peat sites in the boreal zone (IPCC 2014). However, the data mainly originates from the temperate regions and thus the existing EFs for temperate regions appear too high for reporting the GHG fluxes of rewetted agricultural sites as the total of the reviewed emissions were significantly lower compared to the respective IPCC EFs.

The Sphagnum farming sites were sinks of $\mathrm{CO}_{2}$ when the harvest was not included in the balance of $\mathrm{CO}_{2}$ (Table 1). The total net GHG rate without the effect of biomass removal also indicated sink. The harvest was not included in the carbon balance values because, unlike with the emergent plants, the site manager can adjust the harvest rate based on various criteria or even leave all biomass at the site for peat formation. A typical harvest rate of $3.2 \mathrm{t}$ of dry matter (Wichmann et al. 2020) would add close to $6 \mathrm{t} \mathrm{CO}_{2}$ to the annual balance leading to a net emission rate of $3 \mathrm{t} \mathrm{CO}_{2}$ eq. $\mathrm{ha}^{-1} \mathrm{yr}^{-1}$. Overall, the GHG fluxes in restoration and Sphagnum farming did not differ significantly but $\mathrm{N}_{2} \mathrm{O}$ fluxes were higher from restoration.

The sites with emergent plant biomass production were on the average net sources of all GHGs (Table 1). The sites were generally not carbon neutral with respect to $\mathrm{CO}_{2}$ balance and emissions of $\mathrm{CO}_{2}$ and $\mathrm{CH}_{4}$ were generally higher than in the other management types. Emissions of $\mathrm{N}_{2} \mathrm{O}$ were at the same level as those from the restored sites and significantly higher than in Sphagnum farming. The total emissions amounted to $18 \mathrm{t} \mathrm{CO}_{2}$ eq. ha ${ }^{-1} \mathrm{yr}^{-1}$ which is close to the total of the emission factors for shallow-drained grasslands which amount to ca. $15 \mathrm{t} \mathrm{CO}_{2}$ eq. $\mathrm{ha}^{-1} \mathrm{yr}^{-1}$ (IPCC 2014). This is understandable as most of the reviewed field studies were conducted on wet grasslands.

On average, the reviewed sites representing different rewetting types had a climate warming impact of $6.3 \mathrm{t} \mathrm{CO}_{2}$ eq. $\mathrm{ha}^{-1} \mathrm{yr}^{-1}$ (Table 1). The fact that the climatic effect is that high even after considerable management changes illustrates the challenge in GHG mitigation in agricultural peatlands. However, the results also predict significant mitigation potential as the total emissions are still reduced remarkably, approximately by $70-80 \%$ compared to agricultural use of drained peatlands which typically involves emissions in the range 25-35 t CO 2 eq. ha ${ }^{-1} \mathrm{yr}^{-1}$ (IPCC 2014).

The majority of the reviewed sites were monitored during the early phase after rewetting. The net positive GHG balance after rewetting could be, in some cases, a consequence of the fact that such sites are still in a transitional phase and peat-forming vegetation has not yet re-established completely (Wilson et al. 2016b). However, also rising $\mathrm{CH}_{4}$ fluxes after rewetting have been observed (Chamberlain et al. 2018). It is known that in some cases a long time is needed for the recovery of a negative $\mathrm{C}$ balance, from several years to decades (Beyer and Hoeper 2015), while in other sites ecological and $\mathrm{C}$ sink functions similar to pristine peatlands are achieved soon after rewetting (Laine et al. 2019).

Rewetting features the trade-off between $\mathrm{CO}_{2}$ and $\mathrm{CH}_{4}$ emissions; also called the "biogeochemical compromise" (Hemes et al. 2018). Although most of the reviewed sites were net $\mathrm{C}$ sinks in the long term based on their net ecosystem $\mathrm{C}$ balance (Table 1), the relatively high $\mathrm{CH}_{4}$ emissions are a significant component of the total GHG balance and may appear a challenge when using this simplistic approach based on the GWP coefficients. However, radiative forcing modelling that better takes into account the different lifetimes of the GHGs in the atmosphere shows that the increase in $\mathrm{CH}_{4}$ emissions generally does not undermine the climate change mitigation potential of peatland rewetting (Guenther et al. 2020). Ojanen and Minkkinen (2020) made a more disaggregated study and reported that most croplands and grasslands worldwide are among the ecosystems providing net cooling effect when rewetted, at least after some decades. Future research might offer ways to avoid high $\mathrm{CH}_{4}$ emissions by for example targeting rewetting based on site types (Chamberlain et al. 2018).

There are currently two sets of IPCC EFs available for reporting effects of rewetting of agricultural soils: those for shallow-drained grasslands (ground water table higher than $0.3 \mathrm{~m}$ ) and those for rewetted organic soils and the latter are mostly based on studies on other than agricultural soils (IPCC 2014). More disaggregated EFs would be needed to report the GHG mitigation effects of different management 


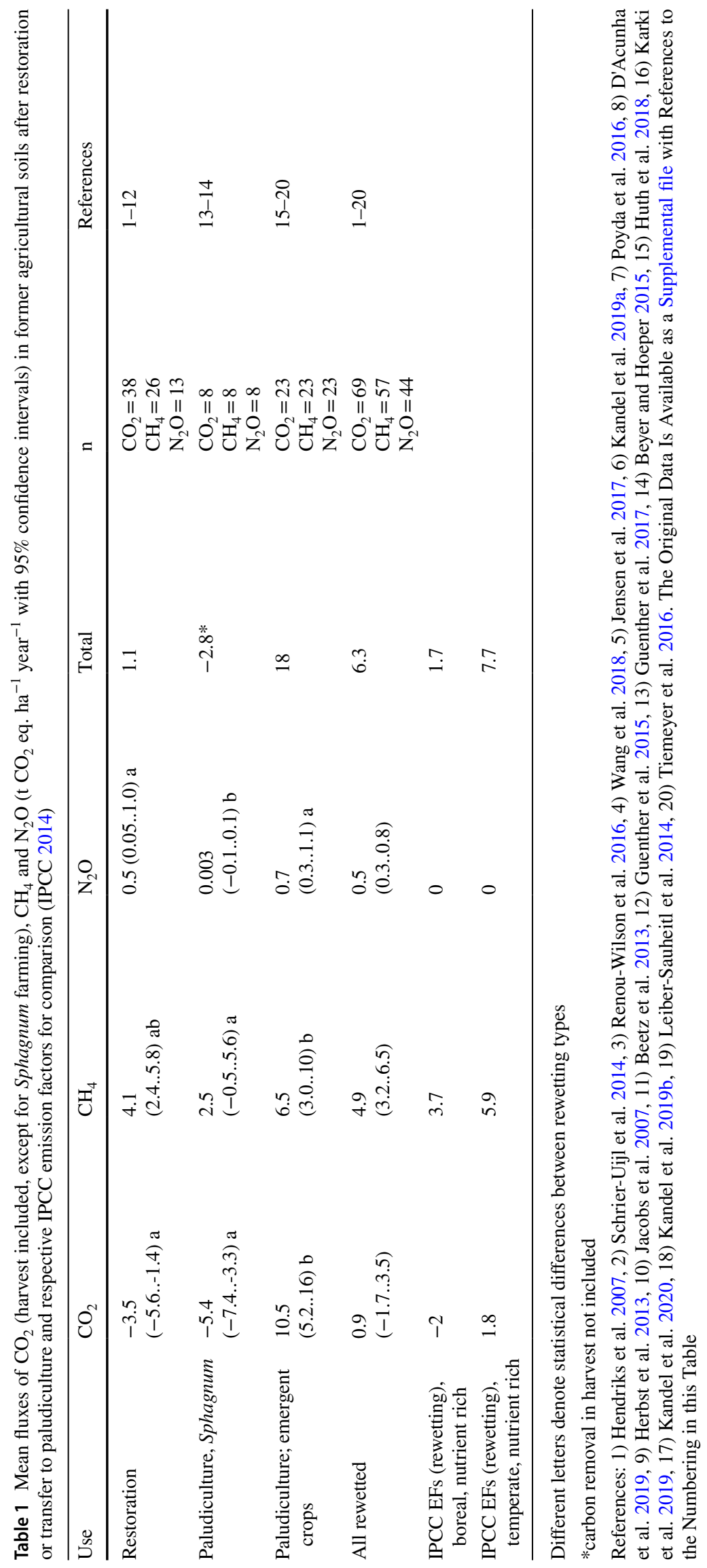


option in different climatic conditions. Our results suggest that the emissions from restoration and Sphagnum farming in temperate zone are overestimated with the corresponding IPCC EFs for rewetting as the measured values were actually closer to the EFs for boreal zone than those for the temperate zone. As for restoration, the new data pool is already quite strong at least in the temperate zone and even the data in Table 1 could be used for emission reporting at least in central Europe from where the data mainly originate from. Paludiculture based on grassland species or other emergent plants, on the other hand, should be reported using the IPCC EFs for shallow drained grasslands rather than those developed for rewetting. It is still to be elucidated which EFs would be suitable for rewetting agricultural sites in the boreal zone as sufficient data are still lacking.

This review suggests that the pool of literature on restoring agricultural soils has grown significantly since the acquisition of the current IPCC emission factors but the data for GHG emissions from paludiculture sites are still scarce. Reporting emissions from paludiculture is thus still very uncertain either with the existing emission factors provided by the IPCC or with the reviewed values of Table 1 . Different rewetting actions are getting more common in the coming years and it is important to have more research for the development of disaggregated emission factors for rewetted agricultural soils in different management options and climate zones.

Supplementary Information The online version contains supplementary material available at https://doi.org/10.1007/s13157-021-01507-5.

Authors' Contributions A.B. extracted most of the data from the literature and wrote the first version of the manuscript, T.L. extracted part of the data and took part in the writing process, H.K., S.S. and K.R. planned the work and took part in writing the paper. All authors read and approved the final manuscript.

Funding This study was funded by the Climate-KIC Pioneers into Practice Programme 2020 of the European Union (A.B.) and the Strategic Research Council of the Academy of Finland (grant number 312931, project Novel soil management practices - key for sustainable bioeconomy and climate change mitigation - SOMPA).

Data Availability The datasets used and analysed during the current study are provided as a supplement.

Code Availability Not applicable.

\section{Declarations}

Ethics Approval We follow the guidelines for the responsible conduct of research and for handling allegations of misconduct (the RCR guidelines) published by the Finnish National Board on Research Integrity TENK, which is appointed by the Ministry of Education and Culture in Finland.

Consent to Participate Not applicable.
Consent for Publication Not applicable.

Conflict of Interest There are no conflicts of interest.

Open Access This article is licensed under a Creative Commons Attribution 4.0 International License, which permits use, sharing, adaptation, distribution and reproduction in any medium or format, as long as you give appropriate credit to the original author(s) and the source, provide a link to the Creative Commons licence, and indicate if changes were made. The images or other third party material in this article are included in the article's Creative Commons licence, unless indicated otherwise in a credit line to the material. If material is not included in the article's Creative Commons licence and your intended use is not permitted by statutory regulation or exceeds the permitted use, you will need to obtain permission directly from the copyright holder. To view a copy of this licence, visit http://creativecommons.org/licenses/by/4.0/.

\section{References}

Beetz S, Liebersbach H, Glatzel S, Jurasinski G, Buczko U, Höper H (2013) Effects of land use intensity on the full greenhouse gas balance in an Atlantic peat bog. Biogeosciences 10:1067-1082

Beyer C, Hoeper H (2015) Greenhouse gas exchange of rewetted bog peat extraction sites and a Sphagnum cultivation site in Northwest Germany. Biogeosciences 12:2101-2117

Canadell JG, Monteiro PMS, Costa MH, Cotrim da Cunha L, Cox PM, Eliseev AV, Henson S, Ishii M, Jaccard S, Koven C, Lohila A, Patra PK, Piao S, Rogelj J, Syampungani S, Zaehle S, Zickfeld K (2021) Global Carbon and other Biogeochemical Cycles and Feedbacks. In: Climate Change 2021: The Physical Science Basis. Contribution of Working Group I to the Sixth Assessment Report of the Intergovernmental Panel on Climate Change [Masson-Delmotte, V., P. Zhai, A. Pirani, S. L. Connors, C. Péan, S. Berger, N. Caud, Y. Chen, L. Goldfarb, M. I. Gomis, M. Huang, K. Leitzell, E. Lonnoy, J.B.R. Matthews, T. K. Maycock, T. Waterfield, O. Yelekçi, R. Yu and B. Zhou (eds.)]. Cambridge University Press. In Press. Available at: https://www.ipcc.ch/report/ar6/wg1/ downloads/report/IPCC_AR6_WGI_Chapter_05.pdf. Accessed 6.10.2021

Chamberlain SD, Anthony TL, Silver WL, Eichelmann E, Hemes KS, Oikawa PY, Sturtevant C, Szutu DJ, Verfaillie JG, Baldocchi DD (2018) Soil properties and sediment accretion modulate methane fluxes from restored wetlands. Global Change Biology 24:4107-4121

Chimner RA, Pypker TG, Hribljan JA, Moore PA, Waddington JM (2017) Multi-decadal changes in water table levels Alter peatland carbon cycling. Ecosystems 20:1042-1057

Couwenberg J, Fritz C (2012) Towards developing IPCC methane 'emission factors' for peatlands (organic soils). Mires and Peat 10:03

D'Acunha B, Morillas L, Black TA, Christen A, Johnson MS (2019) Net ecosystem carbon balance of a peat bog undergoing restoration: integrating $\mathrm{CO} 2$ and $\mathrm{CH} 4$ fluxes from Eddy covariance and aquatic evasion with DOC drainage fluxes. Journal of Geophysical Research-Biogeosciences 124:884-901

FAO (2001) Global forest resources assessment 2000: Main report. FAO forestry paper 140 . FAO, Rome

Guenther A, Huth V, Jurasinski G, Glatzel S (2015) The effect of biomass harvesting on greenhouse gas emissions from a rewetted temperate fen. Global Change Biology Bioenergy 7:1092-1106

Guenther A, Jurasinski G, Albrecht K, Gaudig G, Krebs M, Glatzel S (2017) Greenhouse gas balance of an establishing Sphagnum 
culture on a former bog grassland in Germany. Mires and Peat 20:02

Guenther A, Barthelmes A, Huth V, Joosten H, Jurasinski G, Koebsch F, Couwenberg J (2020) Prompt rewetting of drained peatlands reduces climate warming despite methane emissions. Nature Communications 11:1644

Hemes KS, Chamberlain SD, Eichelmann E, Knox SH, Baldocchi DD (2018) A biogeochemical compromise: the high methane cost of sequestering carbon in restored wetlands. Geophysical Research Letters 45:6081-6091

Hendriks DMD, van Huissteden J, Dolman AJ, van der Molen MK (2007) The full greenhouse gas balance of an abandoned peat meadow. Biogeosciences 4:411-424

Herbst M, Friborg T, Schelde K, Jensen R, Ringgaard R, Vasquez V, Thomsen AG, Soegaard H (2013) Climate and site management as driving factors for the atmospheric greenhouse gas exchange of a restored wetland. Biogeosciences 10:39-52

Huth V, Hoffmann M, Bereswill S, Popova Y, Zak D, Augustin J (2018) The climate warming effect of a fen peat meadow with fluctuating water table is reduced by young alder trees. Mires and Peat 21:04

IPCC (2006) 2006 IPCC Guidelines for National Greenhouse Gas Inventories, Prepared by the National Greenhouse Gas Inventories Programme, Eggleston HS, Buendia L, Miwa K, Ngara $\mathrm{T}$ and Tanabe K (eds). IGES, Japan

IPCC (2014) 2013 Supplement to the 2006 IPCC Guidelines for National Greenhouse Gas Inventories: Wetlands, Hiraishi T, Krug T, Tanabe K, Srivastava N, Baasansuren J, Fukuda M and Troxler TG (eds). IPCC, Geneva, Switzerland

IPCC (2019) Climate Change and Land: an IPCC special report on climate change, desertification, land degradation, sustainable land management, food security, and greenhouse gas fluxes in terrestrial ecosystems. Shukla PR, Skea J, Calvo Buendia E et al. (eds.). Available at: https://www.ipcc.ch/srccl/. Accessed 1.11 .2020

Jacobs CMJ, Jacobs AFG, Bosveld FC, Hendriks DMD, Hensen A, Kroon PS, Moors EJ, Nol L, Schrier-Uijl A, Veenendaal EM (2007) Variability of annual $\mathrm{CO}_{2}$ exchange from Dutch grasslands. Biogeosciences 4:803-816

Jensen R, Herbst M, Friborg T (2017) Direct and indirect controls of the interannual variability in atmospheric $\mathrm{CO} 2$ exchange of three contrasting ecosystems in Denmark. Agricultural and Forest Meteorology 233:12-31

Joosten H (2016) Peatlands across the globe. In: Bonn A, Allott T, Evans M, Joosten H, Stoneman R (eds) Peatland restoration and ecosystem services. Cambridge University Press, Cambridge

Joosten H, Sirin A, Couwenberg J, Laine J, Smith P (2016) The role of peatlands in climate regulation. In: Bonn A, Allott T, Evans M, Joosten H, Stoneman R (eds) Peatland restoration and ecosystem services. Cambridge University Press, Cambridge

Kandel TP, Lærke PE, Hoffmann CC, Elsgaard L (2019a) Complete annual $\mathrm{CO} 2, \mathrm{CH} 4$, and $\mathrm{N} 2 \mathrm{O}$ balance of a temperate riparian wetland 12 years after rewetting. Ecological Engineering 127:527-535

Kandel TP, Karki S, Elsgaard L, Laerke PE (2019b) Fertilizerinduced fluxes dominate annual $\mathrm{N} 2 \mathrm{O}$ emissions from a nitrogenrich temperate fen rewetted for paludiculture. Nutrient Cycling in Agroecosystems 115:57-67

Kandel TP, Karki S, Elsgaard L, Labouriau R, Laerke PE (2020) Methane fluxes from a rewetted agricultural fen during two initial years of paludiculture. Science of the Total Environment 713:136670

Karki S, Kandel TP, Elsgaardl L, Labouriau R, Laerke PE (2019) Annual CO2 fluxes from a cultivated fen with perennial grasses during two initial years of rewetting. Mires and Peat 25:01

Laine AM, Mehtatalo L, Tolvanen A, Frolking S, Tuittila E (2019) Impacts of drainage, restoration and warming on boreal wetland greenhouse gas fluxes. Science of the Total Environment 647:169-181

Leiber-Sauheitl K, Fuss R, Voigt C, Freibauer A (2014) High CO2 fluxes from grassland on histic Gleysol along soil carbon and drainage gradients. Biogeosciences 11:749-761

Leifeld J, Menichetti L (2018) The underappreciated potential of peatlands in global climate change mitigation strategies. Nature Communications 9:1071

Leppelt T, Dechow R, Gebbert S, Freibauer A, Lohila A, Augustin J, Droesler M, Fiedler S, Glatzel S, Hoeper H, Jaerveoja J, Laerke PE, Maljanen M, Mander U, Maekiranta P, Minkkinen K, Ojanen P, Regina K, Stromgren M (2014) Nitrous oxide emission budgets and land-use-driven hotspots for organic soils in Europe. Biogeosciences 11:6595-6612

Nugent KA, Strachan IB, Strack M, Roulet NT, Rochefort L (2018) Multi-year net ecosystem carbon balance of a restored peatland reveals a return to carbon sink. Global Change Biology 24:5751-5768

Ojanen P, Minkkinen K (2020) Rewetting offers rapid climate benefits for tropical and agricultural peatlands but not for forestry-drained peatlands. Global Biogeochemical Cycles 34:e2019GB006503

Poyda A, Reinsch T, Kluss C, Loges R, Taube F (2016) Greenhouse gas emissions from fen soils used for forage production in northern Germany. Biogeosciences 13:5221-5244

Regina K, Nykanen H, Silvola J, Martikainen P (1996) Fluxes of nitrous oxide from boreal peatlands as affected by peatland type, water table level and nitrification capacity. Biogeochemistry 35:401-418

Renou-Wilson F, Mueller C, Moser G, Wilson D (2016) To graze or not to graze? Four years greenhouse gas balances and vegetation composition from a drained and a rewetted organic soil under grassland. Agriculture Ecosystems \& Environment 222:156-170

Saarnio S, Morero M, Shurpali N, Tuittila E-S, Mäkilä M, Alm J (2007) Annual $\mathrm{CO}_{2}$ and $\mathrm{CH}_{4}$ fluxes of pristine boreal mires as a background for the lifecycle analyses of peat energy. Boreal Environment Research 12:101-113

Saarnio S, Winiwarter W, Leitão J (2009) Methane release from wetlands and watercourses in Europe. Atmospheric Environment 43:1421-1429

Schrier-Uijl AP, Kroon PS, Hendriks DMD, Hensen A, Van Huissteden J, Berendse F, Veenendaal EM (2014) Agricultural peatlands: towards a greenhouse gas sink - a synthesis of a Dutch landscape study. Biogeosciences 11:4559-4576

SER (2004) The SER International Primer on Ecological Restoration. Society for Ecological Restoration International. Available at: https://cdn.ymaws.com/www.ser.org/resource/resmgr/custo mpages/publications/SER_Primer/ser_primer.pdf. Accessed 25.8.2021

Strack M, Zuback YCA (2013) Annual carbon balance of a peatland 10 yr following restoration. Biogeosciences 10:2885-2896

Tanneberger F, Schroeder C, Hohlbein M, Lenschow U, Permien T, Wichmann S, Wichtmann W (2020) Climate change mitigation through land use on rewetted peatlands - cross-sectoral spatial planning for Paludiculture in Northeast Germany. Wetlands 40:2309-2320

Tanneberger F, Appulo L, Ewert S, Lakner S, Brolchain NO, Peters J, Wichtmann W (2021) The power of nature-based solutions: how peatlands can help us to achieve key EU sustainability objectives. Advanced Sustainable Systems 5:2000146

Tiemeyer B, Borraz EA, Augustin J, Bechtold M, Beetz S, Beyer C, Droesler M, Ebli M, Eickenscheidt T, Fiedler S, Foerster C, Freibauer A, Giebels M, Glatzel S, Heinichen J, Hoffmann M, Hoeper H, Jurasinski G, Leiber-Sauheitl K et al (2016) High emissions of greenhouse gases from grasslands on peat and other organic soils. Global Change Biology 22:4134-4149 
UN (2019) Resolution adopted by the General Assembly on 1 March 2019 73/284 United Nations Decade on Ecosystem Restoration (2021-2030). Available at: https://undocs.org/A/RES/73/284. Accessed 1.11.2020

Wang M, Wu J, Lafleur PM, Luan J, Chen H, Zhu X (2018) Can abandoned peatland pasture sequestrate more carbon dioxide from the atmosphere than an adjacent pristine bog in Newfoundland, Canada? Agricultural and Forest Meteorology 248:91-108

Wichmann S, Krebs M, Kumar S, Gaudig G (2020) Paludiculture on former bog grassland: profitability of Sphagnum farming in north West Germany. Mires and Peat 26:08

Wilson D, Farrell CA, Fallon D, Moser G, Muller C, Renou-Wilson F (2016a) Multiyear greenhouse gas balances at a rewetted temperate peatland. Global Change Biology 22:4080-4095

Wilson D, Blain D, Couwenberg J, Evans CD, Murdiyarso D, Page SE, Renou-Wilson F, Rieley JO, Sirin A, Strack M, Tuittila E (2016b) Greenhouse gas emission factors associated with rewetting of organic soils. Mires and Peat 17:04

Xu J, Morris PJ, Liu J, Holden J (2018) PEATMAP: refining estimates of global peatland distribution based on a meta-analysis. Catena 160:134-140

Yu ZC (2012) Northern peatland carbon stocks and dynamics: a review. Biogeosciences 9:4071-4085

Publisher's Note Springer Nature remains neutral with regard to jurisdictional claims in published maps and institutional affiliations. 